\title{
Inheritance by Contract Complex Institution Legal Problematic: Applicable Law and Proper Jurisdiction Proving Methodology Creation Necessity
}

\author{
Edward Pilipson \\ Rìga Stradiṇš University, Doctoral Studies Programme "Law", Latvia \\ e.pilipsons@privattiesibas.lv
}

\begin{abstract}
Inheritance by contract complex institution contains two principal, essential areas of legal regulation - inheritance law and law of obligations. These spheres have their own unique character and specific legal order of enforcement - under Private International Law, every sphere of legal regulation has its mandatory rules. Also, due to the complex nature of the institution mentioned above, these two spheres are closely related and often intertwined. These circumstances do not permit the application of the rules of inheritance law apart from the rules of the law of obligations.

Application of foreign law in the territory of the national state is performed through the prism of the analysis of conflict rules contained in separate laws and in the regulations governing inheritance by contract institution. Due to the complexity of the contract of inheritance, it is necessary to analyze and prove the conflict rules relating to inheritance law as well as to the rules of the law of obligations. Because inheritance by contract institution has not yet been fixed in legal doctrine, it is necessary to develop completely new approach to the proof of the applicable law in respect of this institution.

Keywords: applicable law, corresponding law proving procedures, inheritance by contract institution, proper applicable law.

\section{Introduction}

The main problem in applicable law proof under the situation of Private International Law is in the variety of approaches by judges which are denoted by legal system diversity.
\end{abstract}


Edward Pilipson. Inheritance by Contract Complex Institution Legal Problematic:

Applicable Law and Proper Jurisdiction Proving Methodology Creation Necessity

\section{Common Law legal doctrine states that the way}

"to establish by a preponderance of the evidence means to prove that something is more likely so than not so. In other words, a preponderance of the evidence in the case means such evidence as, when considered and compared with that opposed to it, has more convincing force, and produces in your minds belief that what is sought to be proved is more likely true than not true. This rule does not, of course, require proof to an absolute certainty, since proof to an absolute certainty is seldom possible in any case." [1]

The above mentioned statement clearly refers to the standard of proof of the applicable law, which was adopted in Common Law states. In turn, in Civil Law countries the main criterion for the final proof is an inner belief of the judge - civil procedure legal sources in each judgement or decision contain a reasoned part, where a judge or a group of judges argue motives of their decision or judgement [2, 3, 4]. Internal belief appears in three main branches: freedom of choice, internal belief as a legal entitlement, authority or competence. The third branch exists as an electing procedure under the situation of legal order diversification. Applicable law proof procedure is also connected with the two different legal sphere correlation presence. Succession law's main procedural objection is to introduce terms and conditions aligned to succession law, identify the typical timeline of a proper succession, introduce the primary rights and obligations of those who receive inheritance, to understand how to administer a succession when the deceased does not leave a will behind, to understand what portion of an inheritance must go to close relatives and to develop an introductory appreciation of a will and its common components [5]. Vis-à-vis main categories of the law of obligations are contract, quasy contract, obligation and its formation. Despite the situation that succession law institutions can exist as a foundation of the obligation, concretely - testamentary obligation $[6,7]$ or as the termination of the obligation [8] applicable law, connected with this sphere obtains a specific proof methodology. Specific methodology creation to prove applicable law in the situation of inheritance by contract institution is concluded or enforced as demonstrated in the example, cited from practice [9].

Private International Law collision and conflict (term "conflict" involved and adopted in Common Law countries - author's remark) norms concentrated in national legislation have both characteristics of material law and procedural law. Simultaneously, these norms contain principles and regulations which denote international civil procedure governing law direction and its application order. Undoubtedly this statement relates to the inheritance by contract institution. Because of this reason, in the process of proving methodology creation, it seems necessary to maximally avoid procedural component - national state procedural legislation cannot be applied directly within the territory of another state - normative acts restrict this action [10, 11].

Arguing applicable law proof procedure methodology creation necessity under inheritance by contract institution, it seems necessary to demonstrate existence of an analogue situation: Common Law doctrine has two specific ways to prove law under insolvency situation: one is applied as the "chancery rule", which permits a creditor to prove his claims in full, without regard to securities which he holds. The other is 
Edward Pilipson. Inheritance by Contract Complex Institution Legal Problematic:

Applicable Law and Proper Jurisdiction Proving Methodology Creation Necessity

the "bankruptcy rule" under which second creditors are allowed to prove only the balance of their claims above the value of their securities [12]. Existence of two specific proof methods under single and united situation argue that single, arrayed with uniformity legal situation may be disclosed using a plurality of methods. Without doubt, this statement refers to inheritance by contract institution. The main problem in this situation is the absence of uniform and fully completed subject matter - one part of inheritance by contract institution subject matter located in the sphere of succession law, another part - in the sphere of the law of obligations. In turn correlation and mutual interaction of these spheres is located in an unexplored area of legal science. Parties or the court have an opportunity to prove law applicable to inheritance proceeding completely or, for example, in situation under separate institution [13] and to proceeding of obligations apart in parallel litigation but this procedure will not be successful. Inheritance law and law of obligation have separate substantive and, in some situations, separate procedural regulations and as a result different ways for applicable law proof enforcement.

Traditionally, law proving procedure is presented in two forms: matter of law [14] and matter of fact [15]. This segmentation causes problems not only in proving the applicable law both in situations of Civil and Anglo-American law, but also in a situation of necessity to prove applicable law between the states which represent Anglo-American legal family [16]. To provide appropriate proof of applicable law under the inheritance by contract situation, additional reason is reciprocal whether the institution will be present in inheritance by contract complex institution's structure. Alternative nature of reciprocal is whether the institution [17] will give an opportunity to use two ways to prove applicable law - prove law with mandatory demands of succession law or with mandatory demands of obligations law.

Because of this reason, quite an original methodology to prove the law applicable to inheritance by contract institution should be generated.

\section{The Aim of the Study}

The general aim of this paper appears in necessity to create methodology to prove applicable law under the situation of two different and sometimes controversial spheres of legal regulation allegation. Succession law and law of obligations have different objectives in regard to ensure and protect natural rights of individuals. Due to this fact, applicable law which provides introduction, recognition and enforcement of the legal regulation of the national state within the territory of another national state should be proven correct and with sufficient ground. To achieve this aim, it seems necessary to correlate succession law and law of obligation subject matters, analyze them and extrapolate specific methodology to prove applicable law under situation of inheritance by contract complex institution. In turn, to receive this goal, it seems reasonable to distinguish key points for applicable law proof. Traditional key points to prove applicable law in succession law institution's application, recognition and enforcement are terms and 
Edward Pilipson. Inheritance by Contract Complex Institution Legal Problematic:

Applicable Law and Proper Jurisdiction Proving Methodology Creation Necessity

their complexes as follows: a persons' capacity to construct a will, the wills' formal and essential validity, the will's (sometimes, testament - author's remark) construction and, in situation of a will as a unilateral deal, revocation. In turn, traditional key points to prove applicable law in the situation of application of law of obligations institutions recognition and enforcement are terms as follows: formation of an obligation, content of an obligation. Geoffrey Samuel introduced into a system of key points term, named "level of obligation duty" [18].

Important cause to correct applicable succession and obligations law orders is a proper action submitted term limitation: the Civil Law of the Republic of Latvia provides an opportunity to submit inheritance action within a five-year period [19]. In turn German Civil Code (Bürgerliches Gesetzbuches) offers analogical authority within a thirty-year period [20].

Additional purpose to prove proper applicable law is the fact that succession law and law of obligations possess a different public policy (or, sometimes, public order author's remark) comprehension.

\section{Material and Methods}

Realizing the process of examining the objective of this article, the following conventions and laws were used: Convention of 2 October 1973 on the Law Applicable to Maintenance Obligations [21], Convention of 24 October 1956 on the Law Applicable to Maintenance Obligations Towards Children [22], Convention of 5 October 1961 on the Conflicts of Laws Relating to the Form of Testamentary Dispositions [23], Foreign Jurisdiction Act 1890 (1890 Chapter 3753 and 54 Vict) [24], Contracts (Applicable Law) Act 1990 (1990 Chapter 36) [25], Introductory Act to the Civil Code (Einführungsgesetzes zum Bürgerlichen Gesetzbuche) [26], Switzerland's Federal Code on Private International Law [27], Austrian Act on Private International Law (Bundesgesetz vom 15 Juni 1978 über das internationale Privatrecht) [28], Introduction to the Civil Law of the Republic of Latvia [29], Civil Evidence Act 1972 (1972 Chapter 30) [30], other legal acts.

Analytical method, synthesis, legal acts and literature interpretation methods were used.

The objective of this article is to create a completely new methodology for proving applicable law under the situation of inheritance by contract complex institution, and to offer acceptable procedural form to establish a process of proving the applicable law and its execution.

\section{Discussion}

The existence of the law of evidence under situation of provision of applicable law cannot subsist without the theory of proof and without the construction of a clear application of the system of proof. This situation is completely proved by respective 
Edward Pilipson. Inheritance by Contract Complex Institution Legal Problematic:

Applicable Law and Proper Jurisdiction Proving Methodology Creation Necessity

and discrete spheres of legal regulation - the presence of applicable law of succession and applicable laws of obligations in discrete branches clearly demonstrate this issue. The terms "applicable succession law and applicable obligations law" in the context of this article has been used to demonstrate the differences in order of legal regulation. Theory of law should contain a general legal setup of evidence, transforming in sectoral law of evidence, taking into account the specific evidence and subsequent enforcement. Only this approach allows balancing on the basis of uniform branch of the theory of proof and the law of evidence taking into account requirements nominated by inheritance by contract complex institution.

Ronald J. Allen and Brian Leiter examining the law of evidence put forward an interesting system to prove substantive law based on three criteria [31]. First criteria, named with the term "the case of demeanor states that demeanor evidence has little instrumental value as a maximizer of veritistic value" [32]. Second criteria, named with the term "probabilistic evidence" holds as a main category to create evidence match the desired object with reality [33]. The last criteria named with the term "character evidence" approves as main concept situationalism - the authors of the publication state that "people's actions are situation-specific, rather than reflecting stable dispositions constitutive of character" [34].

Summarizing the mentioned above, it seems necessary to approve that in the applicable law the search proceeding under inheritance by contract is the main and discrete intention of institutions; conclusions and enforcement are important in examining applicable succession law and applicable obligations law separately, analyzing their institutions and essential parts exploring interaction opportunities' issues, practically applying the criteria mentioned above.

\section{Methodology Issues to Prove Applicable Succession Law}

To prove applicable law in succession law institutions, following terms and their complexes are used: persons' capacity to construct a will, wills' formal and essential validity, will (sometimes, testament - author's remark) construction and, in situation of will as a unilateral deal, will revocation. In situation under inheritance by contract revocation proceeding should be named with the term "revocation of sui generis succession device". The main category to prove applicable law in succession law institutions is the intention to create succession relationships.

Procedural device to prove applicable succession law is an inheritance action. However, this device cannot be used in all situations - before amendments which have occurred in 2014 in Austrian Civil Code (Allgemeines bürgerliches Gesetzbuch) paragraph 1217 defined relationship with rather complicated way - as to the date of these changes, this material norm in its compound simultaneously cumulated succession, family and obligations legal relationships [35]. Without a doubt inheritance action submitting to prove applicable succession law under this situation is a problematic and doubtful decision. Without questioning, inheritance action to prove and execute 
Edward Pilipson. Inheritance by Contract Complex Institution Legal Problematic:

Applicable Law and Proper Jurisdiction Proving Methodology Creation Necessity

applicable succession law, an authorized person has an opportunity to put before court, under a certain situation, agreements which constituted on the base of part 2 section 2278 of German Civil Code. Due to correct and precise formulations of this norm [36], an authorized person - heir - can submit inheritance action because legacies and testamentary burdens nomination is a testators' personal action directed to property rights constituting and proper concomitant objects' establishment. Obviously property rights legal regime, which corresponds with a concrete object's geographical position, defines competent court to submit inheritance action. However, determination of the competent court to submit an inheritance claim under situation of inheritance by contract is a complicated task even in the case of immovable property succession by concluded inheritance contract. This statement is based on the analysis on the provisions of articles 25 and 41 of the Introductory Act to the Civil Code (Einführungsgesetzes zum Bürgerlichen Gesetzbuche) [37]. Article 25 states that "succession is governed by the law of the country of which the deceased was a national at the time of his death" [38]. In turn article 41 involving the principle of substantially closer connection, which is crucial for different kinds of agreements and contracts, states that

"if there is a substantially closer connection with the law of a country other than that applicable under articles 38 to 40 subarticle 2, then the law of that other country shall apply. (2) a substantially closer connection may be based in particular 1 . on a special legal or factual relationship between the persons involved in connection with the obligation or 2 . in the cases of article 38 subarticles 2 and 3 and of article 39 on the fact, that the persons involved had their habitual residences in the same country at the time of the pertaining facts; article 40 subarticle 2 sentence 2 shall apply mutatis mutandis." [39]

Indeed, this provision establishes applicable law quite successfully and competent court definition in this situation appears as a solved problem. However, application of this provision is impossible because it regulates legal relationships arising from noncontractual obligations. Article 27 of the Introductory Act to the Civil Code, which was provided to regulate a persons' choice of applicable law and to denote competent court, repealed and, by the present moment statement, located on the place of the norm determines applicable law by reference to the law, prescribed by Rome I Regulation [40]. Yet, this regulation does not regulate law applicable to succession [41].

Using inheritance action to denote applicable law in the process of revocation of inheritance by contract device or its nullification is also problematic. It seems necessary to demonstrate this situation on the example of analysis of procedural legislation adopted in Germany and Latvia. German Code of Civil Procedure (Zivilprozessordnung) [42] introduces special rules to submit a claim, separating them into several categories: general jurisdiction of the Germans with their right of extraterritoriality [43], special jurisdiction of the location of the property and the object of the claim [44], exclusive jurisdiction of real action and extended the jurisdiction of hereditary cases [45]. 
Edward Pilipson. Inheritance by Contract Complex Institution Legal Problematic:

Applicable Law and Proper Jurisdiction Proving Methodology Creation Necessity

Civil Procedure Law of the Republic of Latvia [46] regulates submission of the claim requirements without introducing analogical categories which have been adopted by German Code of Civil Procedure. Under inheritance by contract situation, a persons' opportunities to satisfy its own legal interests Civil Procedure Law of the Republic of Latvia offers only two instruments which are concentrated in sections 28 [47] and 29 [48]. The inclusion into inheritance by contract devices' complex action regarding recovery of a child is reasonable - inheritance by contract subject matter in its modern concept appears as a correlation of the subject matter of inheritance law (a legal entity) [49] and the subject of the law of obligations [50]. Because of this claim, providing maintenance can be satisfied with a decision emanating from this action. However, the applicable law in this situation is quite difficult to establish - Convention on the Law Applicable to Maintenance Obligation towards Children [51] states that applicable law in this situation denotes with the child's permanent residence law [52].

Determination of the applicable law in this situation is rather difficult - in this case appears as a correlation between succession law and obligations law. In this situation the main law order to serve this relationship should be defined. In this situation it is possible to represent a decision as follows - a child who receives the funds for maintenance is simultaneously included in the circle of legal heirs in succession law which will be denoted as a managing law. However, this situation makes it impossible to determine appropriate jurisdiction and competent court under succession law requirements German Code of Civil Procedure - to solve this problem, applicable succession law should be achieved as denoted by German Code of Civil Procedure 24 [53], 29 [54] and 28 paragraphs. The mentioned analysis should be created using "character evidence" criteria - only this principle gives true picture of this legal relationship.

Extra contractual nature of maintenance of obligation under situation of succession law norms and discrete institutions mandatory application appears as a complex legal process with complicating element (inheritance by contract institution - author's remark) undoubtedly raising questions concerning the applicable succession law and the relevant jurisdiction consolidation. Maintenance agreement can be concluded before parties' ingoing into inheritance by contract relationships or after the process because "classical contracts are instantaneous, the institution is lasting" [55]. The mentioned fact undoubtedly changes both succession relationship subject matter and obligations from maintenance agreement subject matter. The nature of these changes is not clear and "character evidence" criteria will contribute to denoting of applicable succession law and in establishing proper jurisdiction to proper succession law device conclusion, execution, and, in case of necessity, nullity or revocation.

Inheritance by contract institution as a sui generis legal phenomenon needs special methodology not only in case to prove applicable law for the whole institution but also in situation of proving applicable succession law - legal doctrine states that "the Romans never really developed any general theory about the formation of an obligation and above the various ways in which specific obligation were created" [56]. Continuing this statement in regard to maintenance agreement under the situation of active and 
Edward Pilipson. Inheritance by Contract Complex Institution Legal Problematic:

Applicable Law and Proper Jurisdiction Proving Methodology Creation Necessity

valid inheritance by contract of discrete institution it seems necessary to affirm that the maintenance agreement of the subject matter correlates with essential constitutive parts of inheritance by contract; the discrete institution appears as iuris vinculum [57] and creates specific legal action for applicable succession law. The main category used in law proving the procedure is plausibility. The origin of this term is the two recent United States Supreme Court decisions in cases Ashcroft vs. Iqbal [58] and Bell Atlantic Corp. vs. Twombly [59]. Under the conception of these cases "parties have to allege more than a "short and plain" statement of alleged illegal activities under foreign law" [60]. This conception appears as the most preferable in proving applicable succession law under complicated situations. Short and plain conception does not account the variety of forms to determine applicable succession law. Especially it may appear in a situation of determining the applicable law and jurisdiction with respect to reciprocal will - reciprocal wills are separate instruments of two or more persons, the terms of such wills are reciprocal and ones by which each testator makes testamentary disposition in favor of the other [61]. Additionally, legal nature of reciprocal will has a dual external effect reciprocal wills can be recognized as a contract or a will [62].

In this situation under German procedural law application to denote jurisdiction, a person has an opportunity to choose jurisdiction using German Code of Civil Procedure (Zivilprozessordnung) paragraphs 28 and 29 dispositions - paragraph 28 denotes succession cases extended in jurisdiction (Erweiterter Gerichtsstand der Erbschaft) [63] in turn paragraph 29 denotes a special jurisdiction at the place of execution (Besonderer Gerichtsstand des Erfüllungsorts) [64]. The above mentioned two categories have a fundamental importance in denoting applicable succession law. The main question in this situation is whether it is possible to submit a lawsuit if it is not at the location of the defendant, and on the location of the plaintiff, if the region performed some of the obligations of the parties under the contract from which the dispute has arisen. Solution for this situation: this option is guaranteed to work, if the contract has specified the location of the plaintiff as a place of execution of the contract. If such conditions are not present, the places of performance of certain obligations have not yet considered the place of performance of the contract as a whole. By this moment courts have no common view on the possibility of using an alternative jurisdiction in such circumstances. In this case essential question appears in alternative whether reciprocal will has contractual nature or not. Without doubt, it is a matter of legal qualification of this institution.

In this situation, to confirm general (succession) jurisdiction a person can use the rule which has been described in the article by Pamela J. Stephens "The Single Contract as Minimum Contacts: Justice Brennan "Has it His Way" [65]. The article appears to claim that general (succession) jurisdiction denoting law suits which have contractual nature thus persons have an opportunity to prove using the principle:

"[..] the claim does not arise out of the defendant's contacts or activities in the state, but the defendant has engaged in continuous and systematic activity within the state (or activity within certain territory - author's remark)." [66] 
Edward Pilipson. Inheritance by Contract Complex Institution Legal Problematic:

Applicable Law and Proper Jurisdiction Proving Methodology Creation Necessity

The problem to denote and prove applicable succession material and collision law is testators' citizenship, nationality and domicile. As of the moment, according to relevant regulations' dispositions attach primary importance to these legal institutions. In many cases it causes collisions frequently connected with unstable citizenship presence. This situation should be analyzed on the example of German and Swiss law, regulating citizenship issues. German law allows dual citizenship - this conclusion follows from the analysis of the Nationality Act (Staatsangehörigkeitsgesetz) [67] sections 17 and 25 section 17 regulating loss of German citizenship by acquisition of a foreign citizenship makes an exception for Swiss citizenship holders [68]. Since 1 January 1992 Swiss law also admits dual citizenship [69] - on 23 March 1990 Swiss legislator repealed article 17 of the Federal Act on the Acquisition and Loss of Swiss Citizenship [70]. This dualism is the main problem in denoting and proving applicable succession law - since 30 September 1952 till 23 March 1990 Federal Act on the Acquisition and Loss of Swiss Citizenship (Loi Federale sur l'acquisition et la perte de la nationalité Suisse) allows only single citizenship for a person - article 17 of the Federal Act on the Acquisition and Loss of Swiss Citizenship states that "anyone who wants to naturalize must refrain from approach in order to keep his nationality. Renunciation of foreign nationality should be required if it is reasonable be expected of the applicant" [71] - double citizenship was restricted for Swiss citizens. Accordingly, applicable succession law controls with succession proceeding denoted by a persons' (testator - author's remark) citizenship and coincides with it. Respectively, single (Swiss - author's remark) citizenship gives an opportunity to determine applicable succession law according to mandatory norms prescribed by Swiss legislation [72].

A completely different situation was present till 23 March 1990 - dual citizenship assumption radically changes methodology to prove applicable succession law. Succession contract (sometimes, agreement - author's remark) may contain dispositions the period of performance of which can be defined from 30 September 1952 to 23 March 1990 or from 30 September 1952 to the date which proceeds after 23 March 1990. In the last case, applicable succession law proving the process becomes more complicated than in the situation from 30 September 1952 to 23 March 1990. If a testator under the situation of concluded succession contract in the period from 30 September 1952 to 23 March 1990 adopted a second citizenship, it caused intertemporal collision. This conflict is described in legal literature by the term "progressive juridical situation" [73] and without doubt should be solved by the methodology embodied in the article mentioned above. Solving this problem, it seems necessary to divide the entire relationship in "main relationship" which goes from the moment of the conclusion of succession contract (any moment from 30 September 1952 to 23 March 1990 - author's remark) till succession contract's final and complete execution and "agency relationship" [74]. This relationship goes from 23 March 1990 till succession contract's final and complete execution. Because this separation has blurred boundaries, applicable succession law should be proved by using probabilistic evidence. 
Edward Pilipson. Inheritance by Contract Complex Institution Legal Problematic:

Applicable Law and Proper Jurisdiction Proving Methodology Creation Necessity

In a situation which needs to determine applicable succession law complicated with intertemporal conflict in connection with the presence of dual citizenship, it seems necessary to build a model that will evaluate the benefits of the availability of a particular citizenship. Progressive juridical situation in contradistinction to "instant" juridical situation (for example - drafting the testament - author's remark) is required for building the model to control succession proceeding within the lapse of time. The best tool for the creation of this model - using the probabilistic evidence. This statement is based not only on the base of the situational analysis, but also on doctrinal approach - Henry Prakken in article "On direct and indirect probabilistic reasoning in legal proof" [75] affirms that "there are cases in which reasoning from evidence to hypotheses in legal proof is just as rational as reasoning from hypotheses to evidence, but practically more feasible for lawyers" [76]. Unregulated intertemporal fluctuations between two law orders managing applicable succession law can destroy transfer of rights and legal titles construction. In this situation creating a proper model is the only way to construct applicable succession law methodology.

\section{Methodology Issues to Prove Applicable Obligations Law}

As mentioned above, traditional material law categories to prove applicable obligations law are terms as follows: persons' capacity to conclude and execute agreement or contract, formation of an obligation, and content of an obligation. Geoffrey Samuel introduced important definition into a system of key points, named with term "level of obligation duty" [18]. Methodology to prove applicable obligations law is more complicated than methodology to prove applicable succession law - procedural device to prove applicable obligations law consists of a complex of claims (sometimes, actions - author's remark) covering obligation law in its common definition and, simultaneously, its discrete institutions. The main issue to determine the subject matter of the claim of the law of obligations is its subject matter conception. Roman Private Law denotes this action with formula legis actio per condictionem. Because of this fact, the subject matter definition for these actions is a difficult procedure - George Mousourakis in "Fundamentals of Roman Private Law" [77] states that "the legis actio was essentially a ritual any mistake, even a trivial one, was necessary fatal" [78]. Given the above, it seems valid to say that the key moment to prove applicable law of obligations in a situation of succession by contract; it is the intention of the parties to create obligations relationship with hereditary (succession - author's remark) effect. However, the situation seems to separate obligations relationships from succession - succession law institutions and obligations law institutions are governed by different collision factors and these collision factor mergers in the process of provision could lead to unpredictable consequences.

This conclusion is visible, for example, of succession contract to be concluded in order to Swiss Civil Code article 494. This norm states that "the testator may, by contract of succession, undertake to another person to bequeath his or her estate or 
Edward Pilipson. Inheritance by Contract Complex Institution Legal Problematic:

Applicable Law and Proper Jurisdiction Proving Methodology Creation Necessity

a legacy to that person or a third party" [79]. On the basis of this provision, the nature of the relationships which a testator creates with successor and with a third person is not clear. Analyzing this provision, it may be concluded that with this agreement donation rights are created, traditionally assigned to the law of obligations and the law of succession with the negative character. However, because this statement is only assumptive, the proof of applicable obligations law is complicated by the fact that in a situation this provision creates competition inside the law of obligations governed by such institution. Law of testamentary obligations concentrated in this norm shall be approved by succession component separation from obligation law constituent element. In turn, the law of obligations, emanating from the relationship of the donation should be proven according to the rules of other categories, also related to the law of obligations, but regulated by other connecting factors. In a situation of this proof, one must take into account the fact about the effect of giving the right to inheritance. Also, it should not be an overlooked interaction for the right to inheritance rights obligations.

A possible watershed to separate control law orders can be denoted by Moorcock doctrine [80] which "enables the court (or the person - author's remark) to imply a term because of the special facts of the particular case" [81]. Success of this approach is fixed in Weidner v. Crowther [82] and described by Bertel M. Sparks [83]. In connection with this separation, it seems to indicate a legal relationship folding term iuris vinculum. Under this situation, this symbol denotes donation (gift serving - author's remark) in favor of a third person. Such definition will give legitimacy to this proceeding and denoted individual legal status of the designated donee. Simultaneously, under the mentioned situation, legal relationships between the testator, heir and donee will be ordered. Undoubtedly, the process of proving applicable obligation law will be facilitated - as a result, determining the legal status of the third person will be defined by jurisdiction and the competent court. Proving applicable obligation law in complicated legal situations needs avoidance of presumption of integrity of the mentioned relationship - the third person does not appear as an additional subject in its classical understanding [18]. Simultaneously, donation and its proceeding do not exist as additional objects - this phenomenon exists as an autonomous legal relationship with corresponding consequences.

Some authors put question about presumption of integrity as a basis to relationship [84]; however, placing their statement under doubt due to two reasons: a citizen can never know the true motives for a decision and citizens lack legal knowledge to check the rightness of the decision [84]. This point of view has a right to exist: the concept of the right of succession and main rules of law of obligations have been embedded in the minds of most people. In turn, the concept of complication of the law of obligations and the law of succession by donation often cannot be reflected in the intellectual field. Taking into account the mentioned above, doctrinal and legal separation of the relevant rights appears to be effective and reasonable - applicable obligation law in situation of the concluded succession contract and in situation of donation should be proven 
Edward Pilipson. Inheritance by Contract Complex Institution Legal Problematic:

Applicable Law and Proper Jurisdiction Proving Methodology Creation Necessity

separately. Using presumption of integrity in applicable obligations law proven under the situation mentioned above allows interpreting the donation as a contract of adhesion with undetermined legal nature.

Similar situation has been presented under situation of denoting applicable obligation law relating to most controversial inheritance by contract institution - mutual will. Mutual wills, depending on the applicable law may be qualified as wills (succession law instrument - author's remark) and as a contract (obligation law instrument - author's remark). In this situation, to determine the qualification, sufficient and adequate criteria are required. As Sir Guenter Treitel [85] pointed out, for qualification and proper obligation law denoting it seems necessary to enter and identify the essential conditions and terms of the instrument to ensure that law assigns for institution contractual character [86]. Otherwise, qualifying parties have to provide clear proof of intent. In the situation of Common Law legal norms application extrinsic evidence is looked at in order to determine whether there is a contractual agreement not to revoke the wills without another person's consent (Re Gillesie precedent - author's remark) [87]. By this moment Civil law doctrine and applicable law denoting and enforcing procedures (using conflict and collision law norms - author's remark) do not have sufficient practice to recognize mutual wills as a contract. In turn, in the situation of Common Law norms application contractual character of mutual wills is approved by the mentioned above Re Gillesie precedent. However, this precedent does not solve all questions - an attempt to choose the applicable law by testamentary election will be unsuccessful to the extent that it does not comport with the mandatory features of the otherwise applicable law [88]. However, testamentary election as a device in denoting applicable obligation law cannot be used in law of obligations completely - if no selection is made and used as the principle of implied choice of control right, it can be formed incorrectly - the parties constituting mutual will can accommodate within different territories.

In the situation of a separate agreement between the parties on the definition of the applicable law, unclear status of this agreement appears - the given agreement corresponds with mandatory rules of the law of obligations of the states, which are home to the parties of the mutual will, or the given agreement corresponds with the law of state where it is composed. Restatement (Second) of Conflict of Laws section 187(2) states that

\footnotetext{
"the law of the state chosen by the parties to govern their contractual rights and duties will be applied, even if the particular issue is one which the parties could not have resolved by an explicit provision in their agreement directed to that issue, unless either (a) the chosen state has no substantial relationship to the parties or the transaction and there is no other reasonable basis for the parties' choice" [89].
}

Demonstration of the possible conflicts between the law chosen by the parties of the contract and applicable obligations law displayed in article by Symeon C. Symeonides "The Judicial Acceptance of the Second Conflicts Restatement: A Mixed Blessing" [90]. 
Edward Pilipson. Inheritance by Contract Complex Institution Legal Problematic:

Applicable Law and Proper Jurisdiction Proving Methodology Creation Necessity

Applicable obligations law under inheritance by contract complex institution could be proven by taking into consideration a category named by the term "intime conviction" [91]. This type of proof is used mainly in Common law countries. In a situation of this kind of proof procedure of America procedural legislation of this state, this kind of prove is not only separated from the total mass of evidence, but "it also conceptualizes proof differently" [92]. This view seems to be the best evidence to prove the applicable obligations law in a situation of mutual wills, especially in a situation of appointment of the third person as an heir. As mentioned earlier, the mutual wills, depending on the situation can be recognized as a testament and inheritance (sometimes, succession contract - author's remark) contract. In the first case, the governing law will be testamentary law (hereditary or testamentary statute), in the second case, respectively - obligation law (statute of obligations).

Testamentary law recognizes succession order institution. This institution, in the right of inheritance by will, applies subsidiarity - it takes action in case when testamentary heir has been deemed unworthy. In a situation of testamentary succession, recognizing an unworthy heir, his place is taken by the next heir, in accordance with succession order rules. This step for testators does not create any obligations. Also, any of the rights and forms of their realization do not provide for the unworthy heir. However, in a situation of mutual wills in appointing a third person as an heir is not entirely clear. The heir, recognizing the presumption of contract and acting in a situation of obligation law performs his duties in accordance with the essential conditions of the rules of obligations law in case of his recognition as unworthy, is entitled to recover his costs, made to perform succession contract. In this situation, the question of applicable obligations law arises clearly. Because the transition of inherited property has not taken place, it is necessary for the parties of the contract and the third person (unworthy heir) to agree about the applicable obligations law under which essential rules of property provisions, other material grants and titles which have been carried out in favor of the provision of the testator, will be returned to service an unworthy heir.

Because succession transfer has not taken place, using traditional connecting factors for succession law - lex personalis and lex rei sitate are impossible. Also interested persons cannot use the traditional and fundamental connecting factor for obligation law - lex voluntatis. Usage of connecting factor lex loci contractus is also problematic - mutual will drafting may be held in one place, in turn recognition (qualification) of mutual will as a contract can have another location. In this case, the determination of the applicable obligation law is complicated due to competition between two connecting factors - lex loci contractus and lex loci actus. Under the situation, significant succession contract execution of unworthy heir's activities may be complicated by connecting factor lex loci solutionis. Under this situation, intime conviction evidence seems the most optimal instrument to prove applicable obligations law intime conviction evidence meets the requirements to effectively prove applicable obligations law. 
Edward Pilipson. Inheritance by Contract Complex Institution Legal Problematic:

Applicable Law and Proper Jurisdiction Proving Methodology Creation Necessity

Model of consistency maximization published in article by Christoph Engel in Vermont Law Review [93] serves as a proof to this statement. The use of such evidence makes it possible to divide the applicable obligations law on the following sectors: law of obligations, applicable to the relationship between the testators and the law applicable to the relationship between the testators and the third person - the heir. Discrete denoted relationships would be individualized, and due to these circumstances, each person receives appropriate protection remedy.

\section{Methodology to Prove Applicable Law for Inheritance by Contract Discrete Institutions: Flexible Approach Advisability}

The main problem of creating a methodology to prove the applicable law in inheritance by contract discrete institutions is the absence of the adequate connecting factor for discrete institutions. The presence in inheritance by contract complex institution compounds two spheres of legal regulation - succession law and law of obligations create specific legal regime which should be harmonized by similar, but under the situation of inheritance by contract, often conflicting categories. Due to this circumstance, proving applicable law under inheritance by contract institution as of the moment must be proven in a combined way. First, applicable succession law must be proved. Second, applicable law of obligations should be proved. Only then the law applicable to discrete institutions has to be proved.

From the standpoint of legal regulation, this process has very significant drawbacks. To begin with, separate proof is time-consuming. Additionally, separate proof proceeding leads to the fact that similar categories used in succession law and the law of obligations in legal practice allow for varying interpretations. In turn, the synthesis of individual models and the results of proof can lead to contradictory results and a lack of consistency.

This statement is verified by comparing the legislation of Germany and the Republic of Latvia in the situation of the distribution of succession mass (succession order - author's remark) around the hereditary heirs belonging to the family of the deceased. Civil Law of the Republic of Latvia section 404 establishes four classes of heirs [94]. In turn German Civil Code (Bürgerlichen Gesetzbuches) not only introduces five bursts of inheritance (German Civil Code paragraphs 1924 (Heirs on intestacy of the first degree), 1925 (Heirs on intestacy of the second degree), 1926 (Heirs on intestacy of the third degree), 1927 (More than one share of the inheritance in the case of multiple relationship), 1928 (Heirs on intestacy of the fourth degree), 1929 (More distant degrees), but also establishes a special right of inheritance for spouse who is a relative [95]. Upon agreement between the parties of the succession (or inheritance author's remark) contract on the applicable law within the territory of Germany, likewise within the territory of the Republic of Latvia both Latvian and German law can be applied; the effects of such fact are not clear due to the difference between fundamental principles fixed in succession law and law of obligations. 
Edward Pilipson. Inheritance by Contract Complex Institution Legal Problematic:

Applicable Law and Proper Jurisdiction Proving Methodology Creation Necessity

\section{Martin Werneburg states that}

"the German law of succession is based on four fundamental principles to which many of the succession rules contained in the German Civil Code can be traced back. The principles are: the principle of private succession, the principle of universal succession, the principle of testamentary freedom, the principle of succession by next of kin." [96]

The main principle of the law of obligations named with the term "freedom of contract" explains and regulates many institutions in the sphere of the law of obligations, but extremely broad meaning of this principle does not give answers to the problems of proving applicable law under the situation of inheritance by contract. Because of this, principles of law of obligations system remain open to development and should be created further. The difficulty of proving the applicable law and the possible use of the law of succession of the Republic of Latvia in Germany, applicable under the situation of inheritance by contract are present also in the public policy clause enshrined in the Basic Law for the Federal Republic of Germany "Grundgesetz für die Bundesrepublik Deutschland" [97] - article 14 (Property - Inheritance - Expropriation) states that "property and the right of inheritance shall be guaranteed. Their content and limits shall be defined by the laws. Property entails obligations. Its use shall also serve the public good" [98]. Thus, the order of succession, enshrined in the Civil law of the Republic of Latvia may be rejected by the German law. It seems reasonable to argue that creating a methodology to prove the law applicable to inheritance by contract institution in a situation of necessity to applicate succession law norms prescribed by the Civil Law of the Republic of Latvia in the situation to denote order of succession to probate within the territory of Germany simultaneously eliminates the effect of sections 1924, 1925, 1928, 1929 of the Civil Code of Germany; interested persons have an opportunity to refer to the phrase "property entails obligations" [99].

Civil Law of the Republic of Latvia contains reciprocal will institution (Civil Law of the Republic of Latvia section 606 - author's remark) in certain situations, qualifies as a contract of inheritance also in a situation when the bulk of inherited obligations are enforceable within the territory of Latvia and by the members of the family of the testator, to exclude the action of German succession law in the part of determining the order of succession is quite possible. Undoubtedly, with this action the principle of the law of obligations named with the term "closest and most real connection" [100] often used both in contract law and in the law of obligations will be mediated. The principle's superposition certainly manifests the methodology to create the model to prove the law applicable under the situation of inheritance contract both for main and discrete institutions - succession contract, mutual and reciprocal wills and marriage contracts with testamentary obligations clause. It seems necessary to approve that this model should be appropriate to prove the law under "progressive juridical situations" inheritance by contract institution plus lawful transaction complicated with succession or obligation nature, effect or separate element. 
Edward Pilipson. Inheritance by Contract Complex Institution Legal Problematic:

Applicable Law and Proper Jurisdiction Proving Methodology Creation Necessity

\section{Results and Perspectives for Inheritance by Contract Applicable Law Accentuation and Denoting with Traditional Approaches: Legal Uncertainty Forthcoming Possibility}

1. Inheritance by contract appears as a sui generis [101] legal institution which needs special methodology to prove applicable law.

2. Principle of expediency states that the criterion of preponderance of evidence in the process of proving applicable law under the situation of inheritance by contract institution is more useful than judges' internal belief principle.

3. Judges' internal belief principle possible evolution in its maximization implies, that under the situation of correlation of institutions which belong to different spheres of legal regulation and in a process of stratification of "legislative intents" [102], "judge becomes merely a legal historians and an archaeologists" [103] but not as a creator of law imperatives. Because of this fact applicable law proving procedure becomes less predictable and stable.

4. Legislative intents complex in inheritance by contract institutions, as mentioned above, lead away the process of proving the applicable law in different directions.

5. Proving applicable law under inheritance by contract discrete institutions when applicable succession law and applicable obligation law prove separately, apart from each other there is a presence of risk that applicable law should be proven with undue procedural form: Civil Law of the Republic of Latvia contains two procedural instruments, mediating succession legal relationships and relationships arising from obligations. These two instruments are inheritance action [104] and action complex, arising from obligations law. The concept of action of the law of obligations not specified or concertized - claims from the law of obligations allocated through whole Obligations Law part of Civil Law of the Republic of Latvia. Analogical situation presents in Dutch civil legislation [105]. As a result, applicable succession law may be proven by traditional instruments (with inheritance action - author's remark). In turn, applicable obligations law proving procedure becomes blurred, mixed and diffused.

6. Additional reason which restricts to prove applicable succession law apart from the applicable law of obligations is necessity to harmonize essential parts of the agreements which mediate inheritance by contract institution. For example, succession agreement, fixed in Swiss Civil Code, permits the testator to testate all his or her legacy to third person [106]. In turn Civil Law of the Republic of Latvia does not restrict to testator to alienate movable property in reasonable quantities [107]. This situation demonstrates that in the case of positive result of the proving applicable succession law prescribed by the Swiss Civil Code and its dominance over succession law, prescribed by the Civil Law of the Republic of Latvia potential heir can be disinherited. 
Edward Pilipson. Inheritance by Contract Complex Institution Legal Problematic:

Applicable Law and Proper Jurisdiction Proving Methodology Creation Necessity

7. To avoid the situation mentioned above, it seems necessary to suggest positive result in applicable obligations law proving process - obligation law instruments (discrete institutions) can limit applicable succession law negative influence - under the situation of application of the norms, prescribed by the Civil Law of the Republic of Latvia mentioned above, negative influence can be avoided by sections 1587 [108], 1588 [109] and 1592 [110]. If applicable law mediated by Swiss law discrete institutions negative influence can be limited by mandatory provisions of the Federal Act on the Amendment of the Swiss Civil Code - article 68 of the Federal Act on the Amendment of the Swiss Civil Code allows it [111]. But because of indirect nature of the norm, as mentioned above under the situation of limitation, using Swiss law becomes unstable and unpredictable.

8. Contemporary law doctrine does not recognize procedural form individualization for individually denoted claims - professor David H. Kaye states that "individualization rests more on metaphysical and rhetorical grounds than on scientific and empirical grounds" [112]. For inheritance by contract institution this statement is not acceptable and respectively losses its significance. Inheritance by contract situations and discrete institutions require claim individualization and their selection to a specific group is quite necessary verity of this affirmation demonstrates procedural term to submit appropriate action - inheritance action, a person is authorized to submit before the court, after five years elapses from the day when the right to bring the action has arisen [113]. In turn, the claim arising from the law of obligations could be put before the court within ten years [114].

9. Fixed in Civil Law countries procedural legislation, inner belief of the judging principle under the situation of proving the applicable law under inheritance by contract institution enforcement is difficult to perform. Legal doctrine provides three judges' inner relief main forms: inner relief as a freedom of choice, as legal authority and as an election between several legal alternatives. This particular feature may cause competition of approaches, which is criticized [115].

10. In a given situation, evidential law [116] applicable to inheritance by contract complex institution possesses a "risk of non-persuasion" [117] - analogical determinants, categories and discrete institutions with their essential parts used in succession law or obligations law within the territory of the national state and clothed with evidential ability which proceed from national states' material and collision norms may not be recognized within the territory of another state in case if authorized persons' legal activity recognizes them as part of national states' procedural legislation.

11. Currently, the main procedural instrument to prove and execute applicable law under situation of succession law and law of obligations are inheritance claim and claim (sometimes - actions, author's remark) group, arising from 
Edward Pilipson. Inheritance by Contract Complex Institution Legal Problematic:

Applicable Law and Proper Jurisdiction Proving Methodology Creation Necessity

different objects of the law of obligations. Inheritance claim has vindictive (in rem, rei persecutoriae) nature. In turn actions, arising from the law of obligations, have personal (in personam) abstract and conditional (condictio) nature. This situation does not satisfy the requirements to prove applicable law under situation of inheritance by contract discrete institutions - inheritance by contract institutions allocated within the confines whole legislative act (sometimes, acts - author's remark) which contains norms of material law. This effect can cause claims' competition. This aftermath is possible also in succession law [118].

12. In the process of proving applicable law under inheritance by contract discrete institutions and separate relevant situations (inheritance by contract institution and correlative agreement or contract - author's remark), parties should avoid use of admissible circumstantial evidences. These evidences mediated by different areas of legal regulation and their situational interaction under succession law and obligations law discrete institutions can cause improper imposition and further inaccurate and abnormal proceeding.

\section{Proposals for Future Tendencies: Special Methodology Creation Necessity to Prove Law Applicable to Inheritance by Contract Institution}

1. On the ground of the mentioned above, Professor David H. Kaye's argumentation for applicable law proving procedure creation necessity under inheritance by contract institution should be recognized and affirmed with strong evidences.

2. To create completely new methodology to prove applicable law under the situation of the inheritance by contract discrete institutions, it seems necessary to use as a basis Sopers' law theory system [119] relatively modifying its categories.

3. In the process of new methodology creation, it seems necessary to perceive in Common Law accepted system to prove both material and applicable law proving methodology, which is based on the principle named "preponderance of the evidence". This principle should become the cornerstone of methodology to prove applicable law under inheritance by contract complex institution.

4. Regulation which worked out on the basis of the principle of the preponderance of the evidence, named "preponderance rule" [Kaplow, 2011] requests for "proof beyond a reasonable doubt" [120] criterion introduction. It seems reasonable to point out that only criterion "proof beyond a reasonable doubt" is able to distinguish proofs related to applicable succession law and proofs related to applicable law of obligations. Simultaneously, the criterion 
Edward Pilipson. Inheritance by Contract Complex Institution Legal Problematic:

Applicable Law and Proper Jurisdiction Proving Methodology Creation Necessity

mentioned above assists to authorized persons to produce adequate activity to collecting the proofs under the process of applicable law searching its acceptance and recognition.

5. To prove applicable law, admissible circumstantial evidences may be involved under the situation of joint or "mirror" wills. Due to requirements of the legislation, this class of wills has the ability for instant cancellation, and using admissible circumstantial evidences allows the parties to explore evidences which arise immediately and even instantly, in court proceeding.

6. To prove jurisdiction which promotes to prove applicable law under situation of inheritance by contract complex institution mandatory rules application and simultaneously exclude jurisdiction which is not conducive to a fair resolution of the case, it seems necessary to introduce into the process of proof the applicable law categories named with terms "analytical region" and "normative region". Analytical region for applicable law searching purposes in a situation of inheritance by contract arranges and constructs a system scientific views which focus on specific problems of succession law and law of obligations correlating these problems with inheritance by contract subject matter simultaneously developing it. Normative region for applicable law searching purposes in a situation of inheritance by contract includes a set of rules of succession law and the law of obligations, which in a situation of cross-border application of mandatory rules relates to the national legal system applicable within the range of another legal system. Normative region devices and tools form the legal basis of the perception of norms which in turn form the essential conditions of the inheritance by contract principal and discrete institutions.

7. To correctly prove the law, applicable to inheritance by contract discrete institutions specific claim conception, its procedural form and normative implementation should be elaborated.

\section{Līgumiskās mantošanas tiesiskā problemātika: piemērojamo tiesību un jurisdikcijas noteikšanas metodoloǵijas izveidošanas nepieciešamība}

\section{Kopsavilkums}

Līgumiskā mantošana ietver divas prioritāra rakstura tiesību jomas - mantojuma tiesības un saistỉbu tiesības. Šìm jomām ir savs unikāls raksturs un īpaša piemērošanas un izpildes kārtība - katrai jomai ir savi saistošie noteikumi. Šìs sfēras ir cieši saistītas un savstarpēji korelētas, un tas nosaka šì institūta sarežgìto un komplekso raksturu. Šie apstākḷi neḷauj piemērot mantojuma tiesību sastāvdaḷas atsevišḳi no saistību tiesību 
Edward Pilipson. Inheritance by Contract Complex Institution Legal Problematic:

Applicable Law and Proper Jurisdiction Proving Methodology Creation Necessity

sastāvdaḷām, tāpēc ir nepieciešams analizēt mantojuma un saistību tiesību normas un pierādīt metodolog̣ijas izveidošanas nepieciešamību attiecībā uz piemērojamām mantojuma un saistību tiesību normām, kas regulē tieši līgumisko mantošanu. Tā kā līgumiskā mantošana joprojām nav detalizēti pētīta, ir nepieciešams izstrādāt pilnīgi jaunu pieeju piemērojamo tiesību pierādī̌anai attiecībā uz minēto institūtu.

Atslēgvārdi: līgumiskās mantošanas tiesības, mantojuma tiesības, saistību tiesības, tiesību piemērošanas procedūra.

\section{References}

1. O’Malley, K. F., Grenig, J. E. and Lee, W. C. (eds.). Federal jury practice and instructions (Eagan, MN: Westlaw, 2001). Cited: Mark Schweizer. The civil standard of proof - what is it, actually? Max Planck Institute for Research on Collective Goods, 2013, 2-3.

2. Civil Procedure Law of the Republic of Latvia. Section 193. Form and Contents of a Judgment. In: Civil Procedure Law of the Republic of Latvia. Enacted: 14 October 1998. Into force: 1 March 1999. Published: Latvijas Vēstnesis. 326/330 (1387/1391), 03.11.1998., Ziṇotājs. 23, 03.12.1998. With amendments.

3. Code of Civil Procedure (Germany). Section 313. Form and content of the judgment. In: Code of Civil Procedure (Germany). Enacted: 30 January 1877. Into force: 1 October 1879. Published: RGBl. S. 83. With amendments.

4. Swiss Civil Procedure Code. Article 238. Content. In: Swiss Civil Procedure Code. Enacted: 19 December 2008. Into force: 1 January 2011. Published: SR 272. With amendments.

5. Introduction to the Laws of Timor-Leste. The Law of Succession. Stanford Law School.

6. Civil Law of the Republic of Latvia. Part Four. Obligations Law. Section 1672. In: Civil Law of the Republic of Latvia. Enacted: 28 January 1937. Into force: 1 September 1992. Published: Valdìbas Vēstnesis. 42, 22.02.1937. With amendments.

7. Dutch Civil Code. Section 4.5.3 Testamentary obligations. Article 4:130 Definition of a testamentary obligation. In: Dutch Civil Code. Enacted: 15 May 1829. Into force: 1 October 1830. Published: Dutch Official Journal. With amendments.

8. Swiss Civil Code. Article 322. Statutory entitlement. In: Swiss Civil Code. Enacted: 28 May 1904. Into force: 10 December 1907. Published: BBl, 1904 IV 1, 1907 VI 367. With amendments: amended by No I 1 of the Federal Act of 25 June 1976, in force since 1 Jan. 1978. (AS 1977237 264; BBl 1974 II 1).

9. Proof of Foreign Law after Four Decades with Rule 44.1 FRCP and CPLR 4511. One variable that the reformed rules do not address is the foreign legal system itself. If the issue is the law of England, for example, American judges have little difficulty reading English statutes and cases. Once one crosses into Civil law systems, the difficulties multiply. For third world systems, which may lack case reports and readily accessible published statutes, and whose enforcement may follow often mysterious local customs, not to speak of corruption, the difficulties multiply exponentially. Thus, the law of England may sometimes be treated like the law of an American sister state. In: Proof of Foreign Law after Four Decades with Rule 44.1 FRCP and CPLR 4511. By the Committee on International Commercial Dispute Resolution Association of the Bar of the City of New York. New York City Bar. Available from: http://www.nycbar.org/ [28.05.2015]. 
Edward Pilipson. Inheritance by Contract Complex Institution Legal Problematic:

Applicable Law and Proper Jurisdiction Proving Methodology Creation Necessity

10. Law on the Reform of the Italian Private International Law. Section 12. Law governing the process. In: Law on the Reform of the Italian Private International Law. Enacted: 31 May 1995. Into force: 1 October 1996. Published: Decree No. 214/96. With amendments.

11. Law "On Judicial Power". Section 2. Laws Governing Judicial Power. Law "On Judicial Power”. Enacted: 15 December 1992. Into force: 1 March 1993. Published: Ziñotājs. 1, 14.01.1993. With amendments.

12. Corporations Insolvency Proof of Claims. Indiana Law Journal. 1932, 8 (3), Article 11: 202.

13. Ulrich R. G. The Burden of Proof as to Testamentary Capacity in Wisconsin. Marquette Law Review. 1959; 43 (2): 218-230.

14. Matter of law. That which is determined or ascertained through the use of statutes, rules, court decisions, and interpretations of legal principles. In legal actions the term matter of law is used to define a particular area that is the responsibility of the court. A matter of law can be the basis for an appeal, but generally a matter of fact cannot. Though an appeals court can reverse a decision because of a mistaken matter of law, it will not reverse if the mistake did not affect the verdict. This "harmless error" rule developed, in part, from the recognition that during a trial the court often must make hundreds of decisions based on matters of law. In: The Free Dictionary. By Farlex. Available from: http://legal-dictionary.thefreedictionary.com [03.06.2015].

15. Matter of fact. Matter of fact is procedural determination of the factual complex by the senses or by the testimony of witnesses who describe what they have perceived through the senses of sight, smell, touch, taste, and hearing. Trials are highly complex forums for the consideration of act, opinion, and law. Each area is distinct in its type and in who has responsibility for evaluating it. Courts use the term matter of fact to distinguish a particular kind of information. A fact is a thing done - an actual occurrence or event - and it is presented during a trial in the form of testimony and evidence. The rules of evidence generally allow witnesses to testify as to what they personally know about the facts in dispute, but do not allow witnesses to testify as to their opinions (i.e., thoughts, beliefs, or inferences) in regard to those facts. An exception is made for expert witnesses, whose technical or scientific specialty is considered sufficient to allow them to state their opinion on relevant and material matters. In: The Free Dictionary. By Farlex. Available from: http://legal-dictionary.thefreedictionary.com/matter+of+fact (03.06.2015).

16. Sommerich, O. C., Busch, B. Expert Witness and the Proof of Foreign Law. Cornell Law Review. 1953, 38 (2): 127.

17. Reciprocal will institution according with national legislation requirements can be qualified as a testament or as a contract: Civil Law of the Republic of Latvia states that "a reciprocal will shall be deemed to be also mutual only if the testators have expressly stated their intent to make such a will, or if this is evident from the circumstances of the matter". In: Civil Law of the Republic of Latvia. Part Two. Inheritance Law. Section 606. Enacted: 28 January 1937. Into force: 1 September 1992. Published: Valdìbas Vēstnesis. 42, 22.02.1937. With amendments.

18. Samuel G. Law of Obligations. In: Level of Obligation Duty. Cheltenham: Edward Elgar, 2010. Pp. 32-33.

19. The Civil Law of the Republic of Latvia. Section 685. The right to bring an inheritance action is prescribed after five years have elapsed from the day when the right to bring the action arose (Section 1896). In: The Civil Law of the Republic of Latvia. Part Two. Inheritance Law. Section 606. Enacted: 28 January 1937. Into force: 1 September 1992. Published: Valdìbas Vèstnesis. 42, 22.02.1937. With amendments. 
Edward Pilipson. Inheritance by Contract Complex Institution Legal Problematic:

Applicable Law and Proper Jurisdiction Proving Methodology Creation Necessity

20. German Civil Code. Section 197. Thirty-year limitation period. In: German Civil Code. Book One. Division Five. Enacted: 18 August 1896. Into force: 1 January 1900. Published: Reich Law Gazette. N 21. With amendments.

21. Convention of 2 October 1973 on the Law Applicable to Maintenance Obligations. Concluded: 2 October 1973. Into force: 1 October 1977.

22. Convention of 24 October 1956 on the law applicable to maintenance obligations towards children. Concluded: 24 October 1956. Into force: 1 January 1962.

23. Convention of 5 October 1961 on the Conflicts of Laws Relating to the Form of Testamentary Dispositions. Concluded: 5 October 1961. Into force: 5 January 1964.

24. Foreign Jurisdiction Act 1890. 1890 Chapter 3753 and 54 Vict. Into force: 4 August 1890. With amendments.

25. Contracts (Applicable Law) Act 1990. 1990 Chapter 36. Into force: 26 July 1990. With amendments.

26. Introductory Act to the Civil Code (Einführungsgesetzes zum Bürgerlichen Gesetzbuche). Enacted: 18 August 1896. Into force: 18 August 1896. With amendments.

27. Switzerland's Federal Code on Private International Law. Enacted: 18 December 1987. Into force: 1 January 1989. Published: AS 1988 1776. With amendments.

28. Austrian Act on Private International Law (Bundesgesetz über das internationale Privatrecht). Enacted: 15 June 1978. Into force: 7 July 1978. Published: Federal Law Gazette. No. 304/1978. With amendments.

29. Introduction to the Civil Law of the Republic of Latvia. Enacted: 28 January 1937. Into force: 1 September 1992. Published: Valdìbas Vēstnesis. 41, 20.02.1937. With amendments.

30. Civil Evidence Act 1972. 1972 Chapter 30. Into force: 12 June 1972. With amendments.

31. Leiter, B., Allen, R. J. Naturalized Epistemology and the Law of Evidence. Virginia Law Review. 2001; 87 (8): 1539-1548.

32. Leiter, B., Allen, R. J. Naturalized Epistemology and the Law of Evidence. Virginia Law Review. 2001; 87 (8): 1540.

33. Leiter, B., Allen, R. J. Naturalized Epistemology and the Law of Evidence. Virginia Law Review. 2001; 87 (8): 1543.

34. Leiter, B., Allen, R. J. Naturalized Epistemology and the Law of Evidence. Virginia Law Review. 2001; 87 (8): 1546.

35. General Civil Code of Austria. Paragraph 1217. In: General Civil Code of Austria. Enacted: 1 June 1811. Into force: 1 January 1812. Published: JGS Nr. 946/1811. With amendments before 3 July 2015.

36. German Civil Code. Section 2278. In: German Civil Code. Enacted: 18 August 1896. Into force: 1 January 1900. Published: Reich Law Gazette. No 21. With amendments.

37. Introductory Act to the Civil Code. Enacted: 18 August 1896. Into force: 1 January 1900. Published: RGBl. S. $604 \mathrm{~N} 21$. With amendments.

38. Introductory Act to the Civil Code. Article 25. In: Introductory Act to the Civil Code. Enacted: 18 August 1896. Into force: 1 January 1900. Published: RGBl. S. 604 N 21. With amendments.

39. Introductory Act to the Civil Code. Article 42. In: Introductory Act to the Civil Code. Enacted: 18 August 1896. Into force: 1 January 1900. Published: RGBl. S. 604 N 21. With amendments.

40. Introductory Act to the Civil Code. Fifth Section. Obligations. First Subsection Non-Contractual Obligations. Art. 27-37. [deleted]. [now see Rome I Regulation]. In: Introductory Act to the Civil Code. Enacted: 18 August 1896. Into force: 1 January 1900. Published: RGBl. S. 604 N 21. With amendments. 
Edward Pilipson. Inheritance by Contract Complex Institution Legal Problematic:

Applicable Law and Proper Jurisdiction Proving Methodology Creation Necessity

41. Regulation (EC) No 593/2008 of the European Parliament and of the Council of 17 June 2008 on the law applicable to contractual obligations (Rome I). Article 1. Regulation (EC) No 593/2008 of the European Parliament and of the Council of 17 June 2008. Official Journal L 177, 04/07/2008 Pp. 0006-0016.

42. Zivilprozessordnung. Ursprüngliche Fassung vom 30. Januar 1877. Inkrafttreten am 1. Oktober 1879. Veröffentlicht: RGBl. S. 83. Mit Änderungen.

43. Zivilprozessordnung. $\mathbb{S} 15$. Allgemeiner Gerichtsstand für exterritoriale Deutsche. In: Zivilprozessordnung. Ursprüngliche Fassung vom 30. Januar 1877. Inkrafttreten am 1. Oktober 1879. Veröffentlicht: RGBl. S. 83. Mit Änderungen.

44. Zivilprozessordnung. $\mathbb{\$} 23$. Besonderer Gerichtsstand des Vermögens und des Gegenstands. $\$$ 24. Ausschließlicher dinglicher Gerichtsstand. In: Zivilprozessordnung. Ursprüngliche Fassung vom 30. Januar 1877. Inkrafttreten am 1. Oktober 1879. Veröffentlicht: $R G B l$. S. 83. Mit Änderungen.

45. Zivilprozessordnung. $\mathbb{\$} 28$. Erweiterter Gerichtsstand der Erbschaft. In: Zivilprozessordnung. Ursprüngliche Fassung vom 30. Januar 1877. Inkrafttreten am 1. Oktober 1879. Veröffentlicht: RGBl. S. 83. Mit Änderungen.

46. Civil Procedure Law of the Republic of Latvia. Enacted: 14 October 1998. Into force: 1 March 1999. Published: Latvijas Vēstnesis. 326/330 (1387/1391), 03.11.1998., Ziṇotājs. 23, 03.12.1998. With amendments.

47. Civil Procedure Law of the Republic of Latvia. Article 28. In: Civil Procedure Law of the Republic of Latvia. Enacted: 14 October 1998. Into force: 1 March 1999. Published: Latvijas Vèstnesis. 326/330 (1387/1391), 03.11.1998., Ziñotājs. 23, 03.12.1998. With amendments.

48. Civil Procedure Law of the Republic of Latvia. Article 29. In: Civil Procedure Law of the Republic of Latvia. Enacted: 14 October 1998. Into force: 1 March 1999. Published: Latvijas Vēstnesis. 326/330 (1387/1391), 03.11.1998., Ziṇotājs. 23, 03.12.1998. With amendments.

49. Civil Law of the Republic of Latvia. Section 383. In: Civil Law of the Republic of Latvia. Part two. Inheritance Law. Enacted: 28 January 1937. Into force: 1 September 1992. Published: Valdìbas Vēstnesis. 42, 22.02.1937. With amendments.

50. Civil Law of the Republic of Latvia. Section 1412. Section 1413. Section 1414. In: Civil Law of the Republic of Latvia. Part four. Obligations Law. Enacted: 28 January 1937. Into force: 1 March 1993. Published: Valdïbas Vēstnesis. 46, 26.02.1937. With amendments.

51. Convention on the law applicable to maintenance obligations. Concluded: 25 October 1956.

52. Convention on the law applicable to maintenance obligations. Art. 1. In: Convention on the law applicable to maintenance obligations. Concluded: 25 October 1956.

53. Zivilprozessordnung. $\$ 24$. Ausschließlicher dinglicher Gerichtsstand. In: Zivilprozessordnung. Ursprüngliche Fassung vom 30. Januar 1877. Inkrafttreten am 1. Oktober 1879. Veröffentlicht: $R G B l$. S. 83. Mit Änderungen.

54. Zivilprozessordnung. $\$ 29$. Besonderer Gerichtsstand des Erfüllungsorts. In:Zivilprozessordnung. Ursprüngliche Fassung vom 30. Januar 1877. Inkrafttreten am 1. Oktober 1879. Veröffentlicht: $R G B l$. S. 83. Mit Änderungen.

55. Gottlieb, G. A. G. Relationism: Legal Theory for a Relational Society. University of Chicago Law Review. 1983; 50: 586.

56. Samuel, G. Law of Obligations. Cheltenham, 2010, 28-29.

57. In the Roman law, an obligation is defined as a vinculum juris, i. e., "a bond of law", whereby one party becomes or is bound to another to do something according to law. In: Law Dictionary. Available from: http://thelawdictionary.org/vinculum-juris/ [10.07.2015]. 
Edward Pilipson. Inheritance by Contract Complex Institution Legal Problematic:

Applicable Law and Proper Jurisdiction Proving Methodology Creation Necessity

58. 129 S. Ct. 1937 (2009).

59. 550 U.S. 544 (2007).

60. Michalski, R. M. Pleading and Proving Foreign Law in the Age of Plausibility Pleading. Buffalo Law Review. 2011; 59: 1213.

61. Estate of Lidbury v. Commissioner, 800 F.2d 649, 652.

62. Civil Law of the Republic of Latvia. Part Two. Inheritance Law. Section 606. In: Civil Law of the Republic of Latvia. Enacted: 28 January 1937. Into force: 1 September 1992. Published: Valdìbas Vēstnesis. 42, 22.02.1937. With amendments.

63. Zivilprozessordnung. $\mathbb{S}$ 28. Erweiterter Gerichtsstand der Erbschaft. In: Zivilprozessordnung. Ursprüngliche Fassung vom 30. Januar 1877. Inkrafttreten am 1. Oktober 1879. Veröffentlicht: $R G B l$. S. 83. Mit Änderungen.

64. Zivilprozessordnung. $\$ 29$. Besonderer Gerichtsstand des Erfüllungsorts. In: Zivilprozessordnung. Ursprüngliche Fassung vom 30. Januar 1877. Inkrafttreten am 1. Oktober 1879. Veröffentlicht: RGBl. S. 83. Mit Änderungen.

65. Stephens, P. J. The Single Contract as Minimum Contacts: Justice Brennan "Has it His Way". William \& Mary Law Review. 1986; 28: 89-118.

66. Stephens, P. J. The Single Contract as Minimum Contacts: Justice Brennan "Has it His Way". William \& Mary Law Review. 1986; 28: 99.

67. Nationality Act (Staatsangehörigkeitsgesetz). Enacted: 15 July 1999. Into force: 1 January 2000. Published: Federal Law Gazette. I, 1618. With amendments.

68. Nationality Act (Staatsangehörigkeitsgesetz). Section 17. Loss of citizenship. In: Nationality Act (Staatsangehörigkeitsgesetz). Enacted: 15 July 1999. Into force: 1 January 2000. Published: Federal Law Gazette. I, 1618. With amendments.

69. Swiss nationals applying for nationality in another state do not lose their Swiss nationality, as long as the other state does not require that the person applying for nationality renounce his or her former nationality. Persons applying for Swiss nationality do not have to give up their former ationality, as long as their country of origin allows multiple nationalities. In: Achermann A., Achermann Ch., D’Amato G., Kamm M., Von Rütte B. EUDO Citizenship Observatory. Country Report: Switzerland. San Domenico di Fiesole, 2013, 18.

70. Federal Act on the Acquisition and Loss of Swiss Citizenship. Enacted: 9 August 1951. Into force: 29 September 1952. Published: BBl. 1951 II 669. With amendments. Article 17. Repealed by No. I of the Federal Act of 23 March 1990 (AS 1991 1034; BBl 1987 III 293).

71. Loi Federale sur l'acquisition et la perte de la nationalité Suisse. Art. 17. Double nationalité. In: Loi Federale sur l'acquisition et la perte de la nationalité Suisse. Vu le message du Conseil fédéral du 9 août 1951. Du 29 septembre 1952. Feulle Federale, No. 40.

72. Switzerland's Federal Code on Private International Law. Art. 87. In: Switzerland's Federal Code on Private International Law. Enacted: 18 December 1987. Into force: 1 January 1989. Published: AS 1988 1776. With amendments.

73. Trahan, J.-R. Time for a Change: A Call to Reform Louisiana's Intertemporal Conflicts Law (Law of Retroactivity of Laws). Louisiana Law Review. 1999; 59 (3): 726-728.

74. George, W. Hardy III. Comments on Mire v. Hawkins. Louisiana Law Review. 1966; 27 (1): 13.

75. Prakken, H. On direct and indirect probabilistic reasoning in legal proof. Law, Probability E Risk. 2014; 13.

76. Prakken, H. On direct and indirect probabilistic reasoning in legal proof. Law, Probability E Risk. 2014; 13(3-4): 327-337. 
Edward Pilipson. Inheritance by Contract Complex Institution Legal Problematic:

Applicable Law and Proper Jurisdiction Proving Methodology Creation Necessity

77. Mourakis, G. Fundamentals of Roman Private Law. Berlin: Springer, 2012.

78. Mourakis, G. Fundamentals of Roman Private Law. Berlin: Springer, 2012, 312-313.

79. Swiss Civil Code. Enacted: 28 May 1904. Into force: 10 December 1907. Published: BBl. 1904 IV 1, 1907 VI 367. With amendments.

80. Smith, J. C. The Law of Contract. $4^{\text {th }}$ ed. London, Sweet and Maxvell, 2002.

81. Smith, J. C. The Law of Contract. $4^{\text {th }}$ ed. London, Sweet and Maxvell, 2002, 130.

82. Weidner v. Crowther. 157 Texas 240, 301 S.W.2d 621 (1957).

83. Sparks, B. M. Operation of Joint Wills in Texas. Texas Bar Journal. 1963: 315.

84. Soeharno, J. Is judicial integrity a norm? An inquiry into the concept of judicial integrity in England and the Netherlands. Utrecht Law Review. 2007; 3 I(1): 17.

85. Sir Guenter Treitel, Q.C., D.C.L., F.B.A., Honorary Bencher of Gray's Inn, Formerly Vinerian Professor of English Law.

86. Sir Guenter Treitel. The Law of Contract. London, Sweet and Maxwell, 2003, 149.

87. Re Gillesie (1969), 1 O.R (Ont. C.A.).

88. Bruch, C. S. The Hague Convention on the law applicable to succession to the estates of deceased persons: do quasy-community property and mandatory survivorship law need protection. Law and Contemporary Problems. 1993; 56 (2): 313-314.

89. Restatement (Second) of Conflict of Laws.

90. Symeonides, S. C. The Judicial Acceptance of the Second Conflicts Restatement: A Mixed Blessing. Maryland Law Review. 1997; 56: 1256.

91. Intime Conviction - a French term that means "reasonable conviction; reasonable certainty; state of being satisfied beyond reasonable doubt (personally convinced); personal conviction of the court (after consider'ing all the evidence)". Cited: F. H. S. Bridge. The Council of Europe French-English Legal Dictionary. 2002, 173.

92. Engel, C. Preponderance of the evidence versus intime conviction: a behavioral perspective on a conflict between American and continental Europe law. Vermont Law Review. 2009; 33: 436.

93. Ibid., p. 455.

94. Civil Law of the Republic of Latvia. Part Two. Inheritance Law. Section 404. In: Civil Law of the Republic of Latvia. Enacted: 28 January 1937. Into force: 1 September 1992. Published: Valdìbas Vēstnesis. 42, 22.02.1937. With amendments.

95. German Civil Code. Section 1934. Right of succession of spouse who is a relative. In: German Civil Code. Enacted: 18 August 1896. Into force: 1 January 1900. Published: Reich Law Gazette. N 21. With amendments.

96. Werneburg, M. The Fundamental Principles of the German Law of succession. International Conference "The Perspectives of Europeanization of Law of Succession". Proceedings. Available from: http://pels.edu.pl/ (27.07.2015).

97. Basic Law for the Federal Republic of Germany. Enacted: 8 May 1949. Into force: 23 May 1949. Published: Federal Law Gazette. Part III, classification number 100-1. With amendments. 98. Basic Law for the Federal Republic of Germany. Section 14. In: Basic Law for the Federal Republic of Germany. Enacted: 8 May 1949. Into force: 23 May 1949. Published: Federal Law Gazette. Part III, classification number 100-1. With amendments.

99. Basic Law for the Federal Republic of Germany. Section 14 (2). In: Basic Law for the Federal Republic of Germany. Enacted: 8 May 1949. Into force: 23 May 1949. Published: Federal Law Gazette. Part III, classification number 100-1. With amendments. 
Edward Pilipson. Inheritance by Contract Complex Institution Legal Problematic:

Applicable Law and Proper Jurisdiction Proving Methodology Creation Necessity

100. Giuliano, M., Lagarde, P. Report on the Convention on the law applicable to contractual obligations. Official Journal of the European Communities. No C 282/1.

101. Sui generis - something which is distinct and forms a unique class; the only one of its kind one of a kind; without parallel. A contract or legal right that may resemble other, similar rights but which has a fundamental distinct feature which ought not to be grouped with others. Duhaime.org. Learn Law. Available from: http:/www.duhaime.org/LegalDictionary [06.07.2015].

102. Aharon, B. A Judge on Judging: The Role of a Supreme Court in a Democracy. The Yale Law Journal. 2002. Faculty Scholarship Series. Paper 3692: 75.

103. Aleinikoff, T. A. Updating Statutory Interpretation. Michigan Law Review. 1988; 87 (1): 20-21.

104. Civil Law of the Republic of Latvia. Part Two. Inheritance Law. Section 667. In: Civil Law of the Republic of Latvia. Enacted: 28 January 1937. Into force: 1 September 1992. Published: Valdïbas Vēstnesis. 42, 22.02.1937. With amendments.

105. The word "obligation" refers to the legal effect which may arise from a few different sources. An obligation can be defined as a "legal bond" between two persons, within which one person (the debtor) is legally compelled to carry out a specific performance to which the other person (the creditor) under law is entitled. In: Dutch Civil Law. Available from: http://www. dutchcivillaw.com/content/ [12.06.2015].

106. Swiss Civil Code. Article 494. In: Swiss Civil Code. Enacted: 28 May 1904. Into force: 10 December 1907. Published: BBl. 1904 IV 1, 1907 VI 367. With amendments.

107. Civil Law of the Republic of Latvia. Part Two. Inheritance Law. Section 648. In: Civil Law of the Republic of Latvia. Enacted: 28 January 1937. Into force: 1 September 1992. Published: Valdïbas Vēstnesis. 42, 22.02.1937. With amendments.

108. Civil Law of the Republic of Latvia. Part Four. Obligations Law. Section 1587. In: Civil Law of the Republic of Latvia. Part Four. Obligations Law. Enacted: 28 January 1937. Into force: 1 September 1993. Published: Valdības Vēstnesis. 46, 26.02.1937. With amendments.

109. Civil Law of the Republic of Latvia. Part Four. Obligations Law. Section 1588. One party may not withdraw from a contract without the consent of the other party, even if the latter fails to perform it and due to the failure to perform it. In: Civil Law of the Republic of Latvia. Part Four. Obligations Law. Enacted: 28 January 1937. Into force: 1 September 1993. Published: Valdības Vēstnesis. 46, 26.02.1937. With amendments.

110. Civil Law of the Republic of Latvia. Part Four. Obligations Law. Section 1592. In: Civil Law of the Republic of Latvia. Part Four. Obligations Law. Enacted: 28 January 1937. Into force: 1 September 1993. Published: Valdības Vēstnesis. 46, 26.02.1937. With amendments.

111. Federal Act on the Amendment of the Swiss Civil Code (Part Five: The Code of Obligations). Article 68. In: Federal Act on the Amendment of the Swiss Civil Code (Part Five: The Code of Obligations). Enacted: 1 June 1909. Into force: 30 March 1911. Published: BBl. 1905 II 1, 1909 III 747, 1911 I 695. With amendments.

112. Koeler, J., Saks, M. Individualization claims in forensic science: still unwarranted. Northwestern University School of Law Scholarly Commons, Faculty Working Papers, 2010; Paper 27: 3.

113. Civil Law of the Republic of Latvia. Part Two. Inheritance Law. Section 685. In: Civil Law of the Republic of Latvia. Enacted: 28 January 1937. Into force: 1 September 1992. Published: Valdïbas Vèstnesis. 42, 22.02.1937. With amendments. 
Edward Pilipson. Inheritance by Contract Complex Institution Legal Problematic:

Applicable Law and Proper Jurisdiction Proving Methodology Creation Necessity

114. Civil Law if the Republic of Latvia. Section 1895. In: Civil Law of the Republic of Latvia. Part Four. Obligations Law. Enacted: 28 January 1937. Into force: 1 March 1993. Published: Valdības Vèstnesis. 46, 26.02.1937. With amendments.

115. Zimmerman, E. R. Supplemental standing for severability. Northwestern University Law Review. 2015; 109 (2): 285-342.

116. Evidential law under context of this articles' section - procedural law provided by national collision norms, their collections in material law and legislative practice.

117. Fleming, J., Jr. Burdens of Proof. Virginia Law Review. 1961; 47: 51-55.

118. Hellige, J. R. Right of a Creditor of an Heir to Contest the Will. Notre Dame Law Review, 1971; 50 (2): 309-320. Also: DePaul College of Law. Assignability and Descendibility of Will Contest Rights. DePaul Law Review. 1953; 2 (2): 257-263.

119. Soper's theory of law system: (1) social facts A, B, and C are each necessary and together sufficient conditions for the existence of a legal system. (2) social fact $C$ and noncontingent moral fact $\mathrm{D}$ together are sufficient conditions for the existence of a moral obligation to obey the law. (3) if noncontingent moral fact $\mathrm{D}$ is true, there is a moral obligation to obey the law whenever the conditions for the existence of a legal system are satisfied. In: Burton S. J. Law, Obligation, and a Good Faith Claim of Justice. California Law Review. 1985; 73 (6): 1958.

120. Kaplow, L. Burden of proof. Harvard: John M. Olin Center for Law, Economics, and Business. Discussion Paper. 15 August 2011. Available from: https://law.utexas.edu/wp-content/ uploads/sites/25/kaplow_burden_of_proof.pdf [06.07.2015]. 